\title{
PEREMAJAAN BIBIT RUMPUT LAUT Gracilaria verrucosa HASIL KULTUR JARINGAN MELALUI SELEKSI MASSA
}

\author{
Sri Redjeki Hesti Mulyaningrum, Andi Indra Jaya Asaad, Hidayat Suryanto Suwoyo, dan \\ Erfan Andi Hendrajat
}

Balai Riset Perikanan Budidaya Air Payau dan Penyuluhan Perikanan

Jl. Makmur Dg. Sitakka No. 129, Maros 90512, Sulawesi Selatan

(Naskah diterima: 26 Juli 2019; Revisi final: 19 September 2019; Disetujui publikasi: 19 September 2019)

\begin{abstract}
ABSTRAK
Penelitian ini bertujuan untuk menguji performa bibit rumput laut Gracilaria verrucosa hasil kultur jaringan yang diremajakan dengan metode seleksi massa. Penelitian dilaksanakan di tambak percobaan Marana, Maros, Sulawesi Selatan; menggunakan dua petakan tambak berukuran sekitar $2.500 \mathrm{~m}^{2}$. Seleksi dilakukan berdasarkan perhitungan laju pertumbuhan harian (LPH), menggunakan sistem long line selama dua siklus dengan durasi 30 hari/siklus. Bibit rumput laut hasil seleksi kemudian dipelihara dengan sistem tebar dasar dan dibandingkan dengan kontrol internal dan kontrol eksternal dengan memasang sembilan unit hapa berukuran $1 \mathrm{~m} \times 1 \mathrm{~m} \times 1 \mathrm{~m}$, dengan tiga ulangan untuk masing-masing perlakuan. Perhitungan LPH, kandungan agar, dan kekuatan gel dilakukan setiap 30 hari dan setiap 15 hari dilakukan monitoring terhadap kualitas air yakni salinitas, suhu, nitrat, dan fosfat. Hasil yang diperoleh memperlihatkan adanya peningkatan LPH yang signifikan $(P<0,05)$ dari siklus-I $(2,67 \pm 0,38 \%$ hari $)$ menjadi $(3,56 \pm 0,25 \%$ hari $)$ pada siklus-II, dengan respons seleksi sebesar $21,48 \% 22,34 \%$ dan diferensial seleksi sebesar $9,70 \% 10,16 \%$ Pertumbuhan rumput laut hasil seleksi lebih tinggi (3,23 $\pm 0,50 \%$ hari) dibandingkan dengan kontrol internal $(2,12 \pm 0,02 \%$ hari), dan kontrol eksternal $(1,69 \pm 0,09 \%$ hari $)(P<0,05)$. Kontrol internal memiliki kandungan agar yang lebih tinggi $(20,07 \pm 12,97 \%$ dari rumput laut hasil seleksi $(16,07 \pm 1,58 \%$ dan kontrol eksternal $(8,29 \pm 1,69 \%(P<0,05)$; namun hasil seleksi memiliki kekuatan gel yang lebih tinggi $\left(761,15 \pm 208,90 \mathrm{~g} / \mathrm{cm}^{2}\right)$ dari kontrol internal $\left(322,44 \pm 244,29 \mathrm{~g} / \mathrm{cm}^{2}\right)$, dan kontrol eksternal $(297,42 \pm$ $\left.44,16 \mathrm{~g} / \mathrm{cm}^{2}\right)(\mathrm{P}<0,05)$. Peremajaan bibit rumput laut hasil kultur jaringan dengan metode seleksi massa mampu meningkatkan performa bibit rumput laut $\mathrm{G}$. verrucosa.
\end{abstract}

\section{KATA KUNCl: respons seleksi; diferensial seleksi; G. verrucosa; seleksi massa; peremajaan}
ABSTRACT: Propagation of tissuecultured seaweed seed, Gracilaria verrucosa using mass selection method. By: Sri Redjeki Hesti Mulyaningrum, Andi Indra Jaya Asaad, Hidayat Suryanto Suwoyo, and Erfan Andi Hendrajat

\begin{abstract}
This study was aimed to determine the performance of tissue-cultured seaweed seed Gracilaria verrucosa, which was propagated using mass selection method. The study was conducted in the experimental ponds in Marana, Maros, South Sulawesi. The mass selection was conducted in two ponds of $2,500 \mathrm{~m} 2$. The selection was made by culturing the seaweed seed using the long line system for two cycles in 30 days/cycle duration during which the daily growth rates (DGR) of seaweed seeds were measured. The selected seaweed seeds were then cultivated in the ponds using broadcast system and the growth was compared with the internal and external controls consisted of nine units of $1 \mathrm{~m} \mathrm{x} 1 \mathrm{mx}$ $1 \mathrm{~m}$ hapa, with three replications for each treatment (selected seed, internal control, and external control). The measurements of DGR, agar yield, and gel strength were conducted every 30 days, while water quality monitoring i.e. salinity, temperature, nitrate, and phosphate were conducted every 15 days. The results showed that the DGR of seaweed seed increased significantly $(P<0.05)$ from $2.67 \pm 0.38 \%$ day in cycle-l to $3.56 \pm 0.25 \%$ day in cycle-II, the selection response was $21.48 \% 22.34 \%$ and the differential selection was $9.70 \% 10.16 \%$ The daily growth rate of selected seaweed seed was significantly higher $(3.23 \pm 0.50 \%$ day $)(P<0.05)$ compared to internal $(2.12 \pm 0.02 \%$
\end{abstract}

\footnotetext{
\# Korespondensi: Balai Riset Perikanan Budidaya Air Payau dan

Penyuluhan Perikanan. Jl. Makmur Dg. Sitakka No. 129,

Maros 90512, Sulawesi Selatan, Indonesia.

Tel. + 6241137154

E-mail: mulyaningrum@kkp.go.id
} 
Peremajaan bibit rumput laut Gracilaria verrucosa hasil kultur ..... (Sri Redjeki Hesti Mulyaningrum)

\begin{abstract}
day) and external controls (1.69 $\pm 0.09 \%$ day). Internal control has higher agar yield $(20.07 \pm 12.97 \%$ compared to the selected seed $(16.07 \pm 1.58 \%$ and external control $(8.29 \pm 1.69 \%)(P<0,05)$. The selected seed has higher gel strength $\left(761.15 \pm 208.90 \mathrm{~g} / \mathrm{cm}^{2}\right)$ compared to internal control $\left(322.44 \pm 244.29 \mathrm{~g} / \mathrm{cm}^{2}\right)$, and external control $\left(297.42 \pm 44.16 \mathrm{~g} / \mathrm{cm}^{2}\right)(P<0,05)$. Propagated tissue-cultured seaweed seed using the mass selection method could improve the overall performance of seaweed seed.
\end{abstract}

KEYWORDS: selection response; selection differential; G. verrucosa; mass selection; propagation

\section{PENDAHULUAN}

Rumput laut Gracilaria sp. termasuk spesies yang banyak dibudidayakan untuk tujuan komersil terutama sebagai bahan baku utama agar-agar. Gracilaria merupakan rumput laut yang menempati urutan kedua spesies di dunia yang banyak dibudidayakan khususnya di Cina sebanyak $70 \%$ dan Indonesia sebanyak $28 \%$ dari total produksi global (FAO, 2016). Sekitar $80 \%$ dari total produksi agar-agar di dunia bersumber dari Gracilaria sp. Permintaan pasar dunia terhadap rumput laut Gracilaria sp. terus meningkat seiring dengan peningkatan produksi agar-agar di Eropa, Afrika, Amerika, dan Asia Pasifik (Wikfors \& Ohno, 2001; Bixler \& Porse, 2011).

Penyediaan bibit rumput laut secara konvensional dapat diperoleh dari sumber alam dan perbanyakan vegetatif dari sisa hasil budidaya. Metode penyediaan bibit secara konvesional ini memiliki beberapa kelemahan di antaranya ketersediaan bibit yang sangat tergantung dari kondisi alam, adanya potensi penurunan kualitas rumput laut karena pemakaian bibit yang berulang-ulang dalam beberapa kali siklus budidaya, umur bibit yang melebihi standar, dan tidak ada perbaikan kualitas bibit (Ask \& Azanza, 2002; Graham et al., 2007). Menurut Kim et al. (2017), pemanfaatan bibit dari alam memiliki permasalahan pada variasi fisiologinya seperti pertumbuhan dan kandungan agar. Eksploitasi sumber bibit rumput laut dari alam secara berlebihan memiliki konsekuensi terhadap persoalan ekologi, ekonomi, dan konsekuensi sosial secara global (Titlyanov \& Titlyanova, 2010; Rebours \& Karlsen, 2007). Penggunaan bibit dari sisa hasil budidaya juga menimbulkan permasalahan tersendiri. Budidaya rumput laut menggunakan bibit sisa hasil budidaya juga memungkinkan penurunan kualitas bibit, terbawanya kembali parasit atau patogen dari rumput laut hasil panen sebelumnya pada siklus budidaya selanjutnya dan dapat mengakibatkan penurunan produksi (Hurtado et al., 2006; Vairappan et al., 2008; Saminathan et al., 2015).

Berbagai upaya dilakukan untuk meningkatkan produktivitas seperti perbaikan metode budidaya, perbaikan strain melalui pemanfaatan plasma nutfah yang terseleksi sebagai bibit, perbaikan pengelolaan lahan budidaya, serta perbaikan manajemen budidaya
(Titlyanov \& Titlyanova, 2010; Hurtado et al., 2015). Salah satu metode alternatif untuk mengatasi persoalan-persoalan tersebut adalah penyediaan bibit rumput laut melalui kultur jaringan dan seleksi massa. Salah satu tujuan kultur jaringan adalah propagasi klon rumput laut sebagai bahan baku budidaya. Budidaya rumput laut pada skala komersil memerlukan bibit dengan karakter fenotipe yang diinginkan dalam jumlah besar, kultur jaringan merupakan salah satu metode terbaik untuk menyediakan bibit dalam volume yang besar (Reddy et al., 2008; Yong et al., 2014). Seleksi massa merupakan salah satu teknik pemuliaan tanaman dengan metode pemilihan sekelompok individu dari suatu populasi berdasarkan fenotipe yang serupa. Pada beberapa spesies tanaman, seleksi massa merupakan metode yang penting sebagai upaya untuk meningkatkan kinerja populasi untuk karakter tertentu. Dalam seleksi massa, populasi yang terseleksi biasanya dievaluasi terhadap populasi yang tidak terseleksi untuk mengukur efektivitas seleksi (Luckett \& Halloran, 2003). Pada rumput laut, seleksi massa diaplikasikan untuk memperoleh bibit rumput laut dengan performa yang baik (Pong-Masak et al., 2011).

Balai Riset Perikanan Budidaya Air Payau dan Penyuluhan Perikanan (BRPBAPPP) Maros, telah mengembangkan metode kultur jaringan untuk menyediakan bibit rumput laut $G$. verrucosa, dan hasilnya telah dikembangkan di beberapa lokasi budidaya seperti di Kabupaten Bone (Daud et al., 2013), Maros (Daud et al., 2014), Sinjai (Daud, 2014), Pangkep (Daud et al., 2015), dan Luwu (Makmur \& Mulyaningrum, 2018). Salah satu kendala yang dihadapi dalam pengembangan bibit rumput laut $G$. verrucosa hasil kultur jaringan adalah tidak adanya peremajaan bibit setelah dibudidayakan di tambak. Bibit rumput laut hasil kultur jaringan yang telah dikembangkan di masyarakat digunakan secara berulang-ulang pada beberapa siklus budidaya. Untuk itu, perlu upaya peremajaan bibit rumput laut hasil kultur jaringan dengan metode seleksi massa. Metode seleksi dipilih untuk peremajaan bibit rumput laut hasil kultur jaringan karena metode ini dapat meningkatkan performa bibit rumput laut (Pong-M asak et al., 2011). Penelitian ini bertujuan untuk menguji performa bibit rumput laut $\mathrm{G}$. verrucosa hasil kultur jaringan yang diremajakan dengan metode seleksi massa. 


\section{BAHAN DAN METODE}

\section{Lokasi Penelitian dan Persiapan Tambak}

Penelitian dilaksanakan di Instalasi Tambak Percobaan Marana, Maros, Sulawesi Selatan pada bulan April-Juli 2018 menggunakan dua petakan tambak masing-masing berukuran sekitar $2.500 \mathrm{~m}^{2}$. Sebagai persiapan terlebih dahulu dilakukan pengeringan tambak, kemudian dilakukan pemupukan menggunakan pupuk SP-36 dan pupuk urea dengan perbandingan $1: 2$ atau $25 \mathrm{~kg}$ (SP-36) dan $50 \mathrm{~kg}$ (urea) untuk setiap petak dengan dosis $250 \mathrm{~kg} / \mathrm{ha}$. Petakan1 digunakan untuk seleksi rumput laut hasil kultur jaringan dengan metode long line, sedangkan petakan2 untuk pemeliharaan rumput laut hasil seleksi.

\section{Seleksi Bibit}

Bibit rumput laut yang digunakan merupakan bibit hasil kultur jaringan hasil penelitian tahun 2013 (Mulyaningrum et al., 2014) yang telah dibudidayakan di tambak masyarakat. Seleksi dilakukan berdasarkan perhitungan laju pertumbuhan harian (LPH) menggunakan sistem long line sesuai dengan metode yang dikembangkan oleh Pong-Masak et al. (2011). Rumput laut hasil kultur jaringan ditimbang sebanyak $30 \mathrm{~g}$ setiap rumpun dan diikat pada tali bentangan dengan panjang sekitar $30 \mathrm{~m}$ dengan jarak antar rumpun $15-20 \mathrm{~cm}$. Setiap bentangan diikat pada bambu pancang dengan ketinggian $15-20 \mathrm{~cm}$ dari dasar tambak.

Seleksi dilakukan selama dua siklus dengan lama pemeliharaan 30 hari/siklus. Pada akhir setiap siklus seleksi, yakni 30 hari dilakukan pengukuran LPH dengan menimbang bobot setiap rumpun. Pengukuran LPH dilakukan pada semua rumpun dengan menimbang rumpun satu per satu. Bibit rumput laut dengan LPH tertinggi-1 merupakan bibit rumput laut yang terseleksi, sedangkan bibit yang tidak terseleksi digunakan sebagai kontrol internal. Penentuan karakter pertumbuhan bibit rumput laut hasil seleksi dilakukan dengan menghitung respons seleksi dan diferensial seleksi. Respons seleksi $(\Delta \mathrm{G})$ merupakan selisih antara bobot rata-rata populasi terseleksi (Ps) dan bobot rata-rata kontrol (PC). Diferensial seleksi (S) merupakan selisih antara bobot rata-rata populasi terseleksi $\left(x^{\prime}\right)$ dan bobot rata-rata populasi awal $(x)$ (Luckett \& Halloran, 2013).

Bibit yang terseleksi kemudian dipelihara dengan sistem tebar dasar (broadcast system) pada petakan yang telah disiapkan sebelumnya dengan kepadatan 1.250 $\mathrm{kg} /$ petak.

\section{Pemeliharaan Bibit Hasil Seleksi}

Bibit rumput laut hasil seleksi dipelihara dengan sistem tebar dasar (broadcast system) pada petakan yang telah disiapkan. Selama pemeliharaan dilakukan pemupukan susulan dengan pupuk urea setiap 15 hari dengan dosis 10\%dari pemupukan awal (5 kg/petak).

Performa bibit rumput laut hasil seleksi dibandingkan dengan kontrol internal dan kontrol eksternal (bibit lokal) yang merupakan rumput laut hasil budidaya di sekitar lokasi penelitian. Monitoring performa bibit rumput laut dilakukan dengan memasang sembilan unit hapa berukuran $1 \mathrm{~m} \times 1 \mathrm{~m}$, dengan tiga hapa untuk masing-masing sumber bibit (seleksi, kontrol internal, dan kontrol eksternal). Setiap hapa diisi rumput laut dengan bobot awal 500 g/hapa dan dipasang secara acak pada bagian inlet, tengah, dan outlet tambak. Analisis pertumbuhan, kandungan agar, dan kekuatan gel dilakukan setiap 30 hari; sedangkan pengamatan kualitas air yang meliputi salinitas, suhu, nitrat, dan fosfat dilakukan setiap 15 hari. Kandungan agar dianalisis dengan metode ekstraksi air panas dan kekuatan gel dianalisis dengan alat Brookfield CT3 Texture Analyser mengacu pada metode Ahmad et al. (2011) dengan konsentrasi agar sebesar 3\%(b/v) sesuai metode Indriawati (2007).

\section{Analisis Data}

Data pertumbuhan rumput laut pada seleksi siklusI dan II dianalisis secara statistik dengan analisis uji t untuk mengetahui apakah terdapat perbedaan pertumbuhan pada siklus-I dan siklus-II. Data pertumbuhan rumput laut hasil seleksi, kontrol internal dan kontrol eksternal, kandungan agar dan kekuatan gel rumput laut dianalisis secara statistik menggunakan analisis ragam (ANOVA) dan uji lanjut Duncan. Data respons seleksi, diferensial seleksi, dan kualitas air yakni salinitas, suhu, nitrat, dan fosfat dianalisis secara deskriptif.

\section{HASIL DAN BAHASAN}

\section{Pertumbuhan}

Seleksi bibit selama dua siklus dengan metode long line memperlihatkan peningkatan LPH bibit rumput laut hasil seleksi, di mana pada siklus-II LPH rata-rata sebesar (3,56 $\pm 0,25 \%$ hari) lebih tinggi daripada siklus I (2,67 $\pm 0,38 \%$ hari) (Gambar 1). Hasil analisis uji t memperlihatkan bahwa pertumbuhan rumput laut pada seleksi siklus-I berbeda nyata dengan siklus-II $(P<0,05)$. 


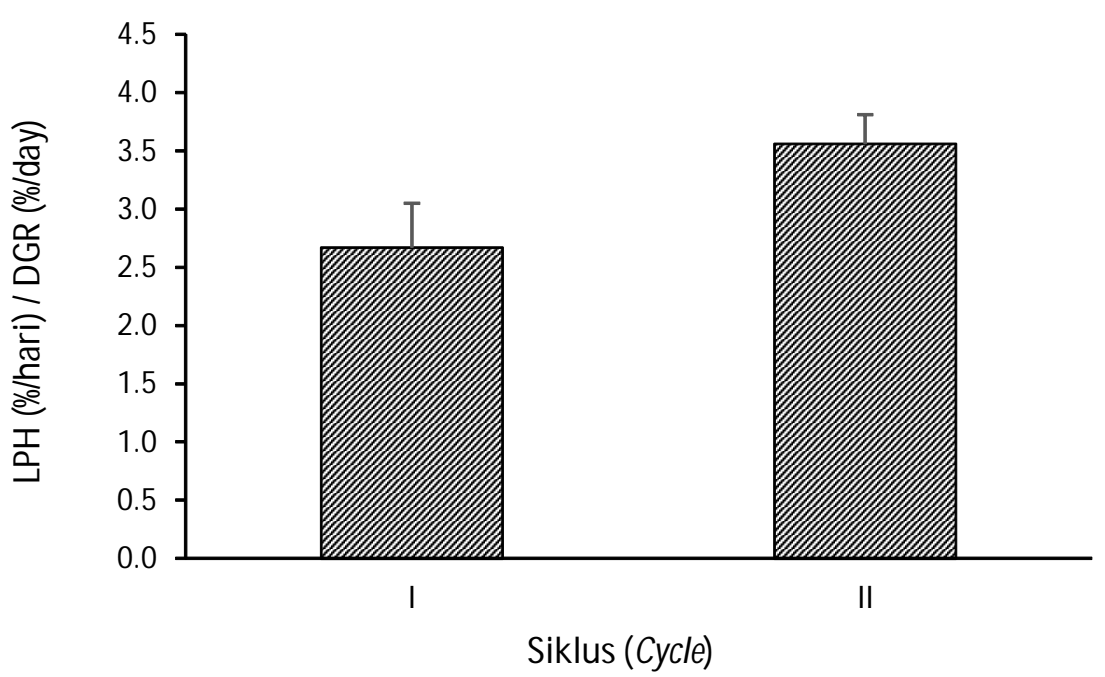

Gambar 1. Laju pertumbuhan harian rumput laut G. verrucosa pada seleksi bibit selama dua siklus.

Figure 1. Daily growth rate of $\mathbf{G}$. verrucosa on two cycles seed selection.

Performa pertumbuhan bibit rumput laut pada setiap rumpun juga nampak semakin membaik dari siklus-I hingga siklus-II. Hal ini dapat dilihat secara visual pada siklus-II rumput laut memiliki rumpun yang lebih rimbun dengan percabangan yang lebih banyak dibanding pada siklus-I (Gambar 2).

Dari hasil analisis pola pertumbuhan rumput laut (Tabel 1), diperoleh estimasi respons seleksi pada kisaran 12,17-25,76 g atau sebesar 21,48\%22,34\%dan diferensial seleksi pada kisaran 6,20-12,88 g atau sebesar $9,70 \% 10,16 \%$ Respons seleksi dan diferensial seleksi yang diperoleh pada penelitian lebih rendah dari hasil yang diperoleh Parenrengi et al. (2016) pada rumput laut Kappaphycus striatum di mana estimasi respons seleksi berada pada kisaran $66,48 \% 100 \%$ dan diferensial seleksi 47,5\%75,17\% Pong-Masak \& Sarira (2018) melaporkan seleksi pada rumput laut Kappaphycus alvarezii dapat meningkatkan pertumbuhan rumput laut hasil seleksi sebesar 5,53\% hari dari kontrol 2,19\%/hari.

Menurut Ariyanto (2015), seleksi harus memperhatikan latar belakang populasi yang akan diseleksi sehingga respons seleksi yang diperoleh sesuai harapan. Respons seleksi merupakan indikasi kemajuan hasil seleksi, hasil yang diharapkan dari seleksi rumput laut adalah meningkatnya rata-rata bobot rumpun rumput laut pada suatu populasi. Salah satu faktor yang memengaruhi respons seleksi adalah diferensial seleksi. Nilai diferensial seleksi dapat ditingkatkan dengan memperkecil jumlah rumpun yang
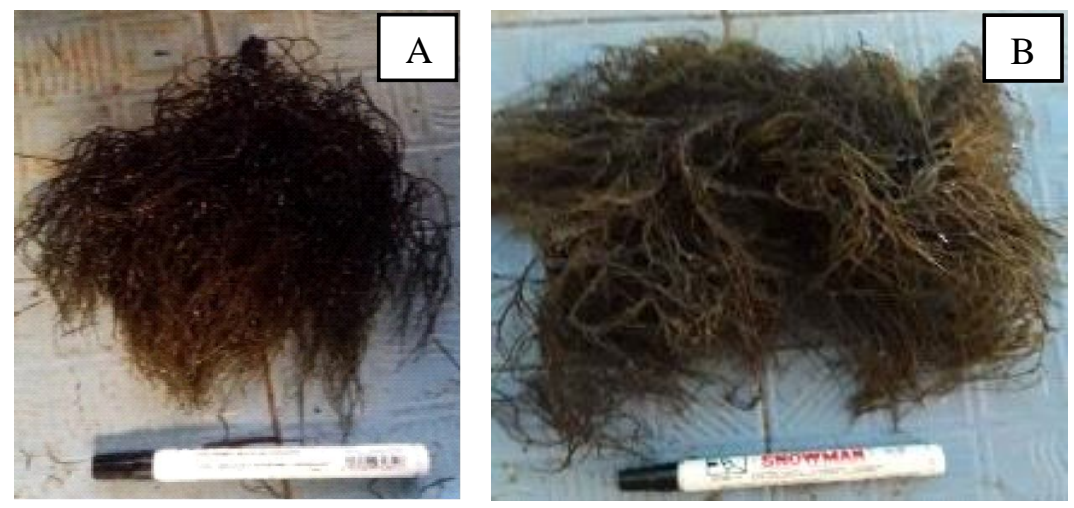

Gambar 2. Performa rumpun bibit rumput $\mathrm{G}$. verrucosa laut hasil kultur jaringan pada siklus-I (A) dan siklus-II (B).

Figure 2. Clump performance of tissue cultured seaweed $\mathbf{G}$. verrucosa seed on cycle-l (A) and cycle-ll (B). 
Tabel 1. Respons seleksi dan diferensiasi seleksi rumput laut G. verrucosa hasil seleksi berdasarkan karakter bobot

Table 1. Selection response and differential selection of seaweed seed G. verrucosa based on weight character

\begin{tabular}{lcc}
\hline \multicolumn{1}{c}{ Peubah (Nariables) } & $\begin{array}{c}\text { Seleksi-I } \\
\text { Mass selection-I }\end{array}$ & $\begin{array}{c}\text { Seleksi-II } \\
\text { Mass selection-II }\end{array}$ \\
\hline Bobot rata-rata populasi kontrol (W eight of non selected seed) $(\mathrm{g})$ & 54.93 & 119.94 \\
Bobot rata-rata populasi terseleksi (W eight of selected seed) $(\mathrm{g})$ & 67.20 & 145.70 \\
Bobot rata-rata populasi bibit (W eight of seed population) $(\mathrm{g})$ & 61.00 & 132.82 \\
Respons seleksi (Response to selection) $(\mathrm{g})$ & 12.27 & 25.76 \\
Diferensiasi seleksi (Differiential of selection) $(\mathrm{g})$ & 6.20 & 12.88 \\
\hline
\end{tabular}

diseleksi, semakin kecil jumlah rumpun yang diseleksi semakin besar nilai diferensial seleksi, sehingga kemajuan hasil seleksi per generasi akan semakin besar.

LPH rumput laut pada perbanyakan bibit dengan meto de tebar dasar selama dua siklus seperti disajikan pada Tabel 2. Rata-rata LPH rumput laut dari siklus-I dan siklus-II, hasil seleksi lebih tinggi $(3,23 \pm 0,50 \%$ hari) dibandingkan dengan kontrol internal $(2,12 \pm$ 0,02\% /hari), dan kontrol eksternal (1,69 $\pm 0,09 \%$ hari).

Hasil analisis ragam (ANOVA) memperlihatkan bahwa seleksi bibit berpengaruh signifikan terhadap pertumbuhan rumput laut $G$. verrucosa baik pada siklusI maupun siklus-II $(P<0,05)$.

Peremajaan bibit dengan metode seleksi massa selama dua siklus telah memperlihatkan peningkatan pertumbuhan bibit rumput laut, meskipun kisaran LPH yang diperoleh pada penelitian ini masih lebih rendah dari kisaran LPH pada uji multilokasi bibit rumput laut hasil kultur jaringan pada beberapa daerah yang telah dilakukan pada penelitian sebelumnya (Tabel 3).

Perbedaan pertumbuhan ini diduga karena umur bibit rumput laut yang sudah lama dan pemakaian bibit hasil kultur jaringan yang berulang-ulang untuk budidaya. Menurut Hurtado \& Cheney (2003), metode konvensional dengan menggunakan $10 \% 40 \%$ sisa hasil panen untuk siklus budidaya berikutnya dapat menyebabkan penurunan keragaman genetik, penurunan $\mathrm{LPH}$, dan kandungan agar, serta peningkatan risiko penyakit.

\section{Kandungan Agar dan Kekuatan Gel}

Kandungan agar rumput laut hasil seleksi $(17,18$ $\pm 2,76 \%$ yang diperoleh pada siklus-I lebih tinggi daripada kontrol internal $(10,9 \pm 1,00 \%$ ), dan kontrol eksternal $(9,48 \pm 0,24 \%$. Pada siklus-II kandungan agar rumput laut kontrol internal $(29,24 \pm 0,86 \%$ lebih tinggi dari hasil seleksi $(14,95 \pm 0,67 \%$, dan kontrol eksternal $(7,09 \pm 2,19 \%$ (Gambar 3). Kandungan agar rata-rata selama dua siklus pemeliharaan menunjukkan kontrol internal $(20,07 \pm 12,97 \%)$ lebih tinggi dari hasil seleksi $(16,07 \pm 1,58 \%$, dan kontrol eksternal $(8,29 \pm 1,69 \%$.

Hasil analisis ragam (ANOVA) memperlihatkan bahwa ketiga sumber bibit memiliki kandungan agar yang berbeda nyata $(P<0,05)$. Uji lanjut Duncan memperlihatkan perbedaan yang signifikan $(P<0,05)$

Tabel 2. Laju pertumbuhan harian pada 30 hari masa pemeliharaan bibit rumput laut $\mathrm{G}$. verrucosa pada siklus-I dan II dengan sistem tebar dasar

Table 2. Daily growth rate of seaweed seed $\mathbf{G}$. verrucosa during 30 days cultivation on cycle-I and II using broadcast farming system

\begin{tabular}{lcc}
\hline \multicolumn{1}{c}{$\begin{array}{c}\text { Bibit rumput laut } \\
\text { Seaweed seed }\end{array}$} & \multicolumn{2}{c}{ LPH (\%hari) (DGR (\%day)) } \\
\cline { 2 - 3 } & Siklus-I (Cycle-l) & Siklus-II (Cycle-ll) \\
\hline Seleksi (Selected seed) & $2.88 \pm 0.16^{\mathrm{a}}$ & $3.59 \pm 0.23^{\mathrm{a}}$ \\
Kontrol internal (Internal control) & $2.10 \pm 0.65^{\mathrm{ab}}$ & $2.13 \pm 0.09^{\mathrm{b}}$ \\
Kontrol eksternal (External control) & $1.63 \pm 0.12^{\mathrm{b}}$ & $1.75 \pm 0.10^{\mathrm{c}}$ \\
\hline
\end{tabular}

Keterangan: Nilai dengan superskrip yang sama setelah nilai rata-rata menunjukkan tidak berbeda nyata $(P>0,05)$ pada uji Duncan

Note: Values with the same superscripts after means value are not significantly different $(P>0.05)$ in Duncan test 
Tabel 3. Laju pertumbuhan harian rumput laut G. verrucosa hasil kultur jaringan dengan metode budidaya tebar dasar pada berbagai lokasi

Table 3. Daily growth rate of tissue cultured seaweed G. verrucosa using broadcast farming system in several locations

\begin{tabular}{lcc}
\hline $\begin{array}{c}\text { Lokasi } \\
\text { Location }\end{array}$ & $\begin{array}{c}\text { Kisaran LPH (\%hari) } \\
\text { DGR range (\%day) }\end{array}$ & $\begin{array}{c}\text { Referensi } \\
\text { Reference }\end{array}$ \\
\hline Bone & $3.80-3.82$ & Daud et al . (2013) \\
Maros & $4.22-6.01$ & Daud et al . (2014) \\
Sinjai & $4.31-4.86$ & Daud (2014) \\
Pangkep & $5.32-5.92$ & Daud et al . (2015) \\
Luwu & $3.91-5.60$ & Makmur \& Mulyaningrum (2018) \\
Maros $^{*}$ & $2.88-3.59$ & - \\
\hline
\end{tabular}

Keterangan (Note): * Hasil yang diperoleh pada penelitian ini (Result of the present study)

pada kandungan agar hasil seleksi, kontrol internal, dan kontrol eksternal baik pada siklus-I dan siklus-II.

Hasil penelitian ini lebih tinggi dari hasil yang diperoleh oleh Rejeki et al. (2018) yang memperoleh kandungan agar rumput laut $\mathrm{G}$. verrucosa hasil kultur jaringan sebesar 8,4\%dengan sistem budidaya tebar dasar. Mulyaningrum \& Suwoyo (2018) melaporkan kandungan agar rumput laut $\mathrm{G}$. verrucosa hasil kultur jaringan yang dibudidayakan dengan metode long line berada pada kisaran 10,30 \pm 2,15-27,84 $\pm 1,0 \%$ Menurut Villanueva et al. (2010), kandungan agar rumput laut Gracilaria sp. berada pada kisaran 15\% $33 \%$
Rumput laut hasil seleksi memiliki kekuatan gel lebih tinggi daripadakontrol internal maupun kontrol eksternal baik pada siklus-I dan siklus-II. Kekuatan gel rumput laut hasil seleksi pada siklus-I $(613,44 \pm 54,49$ $\left.\mathrm{g} / \mathrm{cm}^{2}\right)$ lebih tinggi dari kontrol internal $(149,70 \pm$ $\left.36,33 \mathrm{~g} / \mathrm{cm}^{2}\right)$, dan kontrol eksternal $(328,64 \pm 42,59$ $\left.\mathrm{g} / \mathrm{cm}^{2}\right)$. Hal yang sama juga terjadi pada siklus-II di mana kekuatan gel hasil seleksi sebesar $(908,86 \pm$ $\left.65,14 \mathrm{~g} / \mathrm{cm}^{2}\right)$, kontrol internal $\left(495,18 \pm 1,25 \mathrm{~g} / \mathrm{cm}^{2}\right)$, dan kontrol eksternal $\left(266,19 \pm 21,92 \mathrm{~g} / \mathrm{cm}^{2}\right)$ (Gambar 4). Nilai rata-rata hasil seleksi $(761,15 \pm 208,90 \mathrm{~g} /$ $\left.\mathrm{cm}^{2}\right)$, kontrol internal $\left(322,44 \pm 244,29 \mathrm{~g} / \mathrm{cm}^{2}\right)$, dan kontrol eksternal $\left(297,42 \pm 44,16 \mathrm{~g} / \mathrm{cm}^{2}\right)$. Rumput

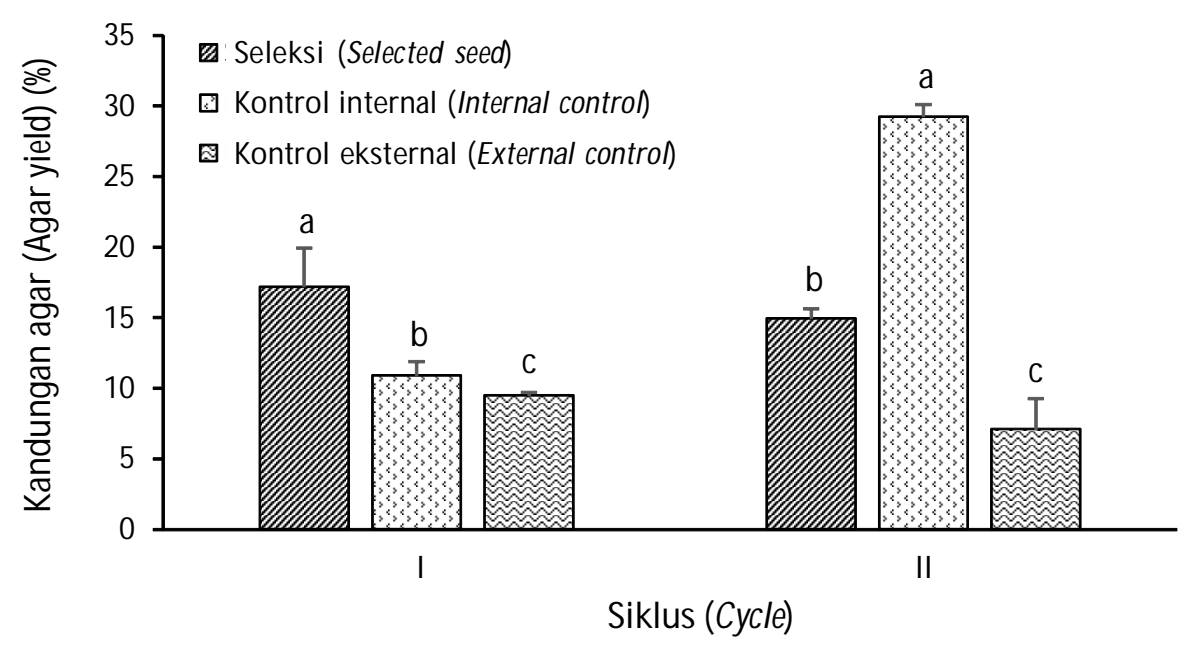

Keterangan: Nilai yang diikuti oleh huruf yang sama setelah nilai rata-rata menunjukkan tidak berbeda nyata $(P>0,05)$ pada uji Duncan

Note: $\quad$ Values with the same superscripts after means value are not significantly different $(P>0.05)$ in Duncan test

Gambar 3. Kandungan agar bibit rumput laut pada umur 30 hari pada siklusI dan II.

Figure 3. Agar yield of seaweed seed after 30 days cultivation in cycle- I and II. 


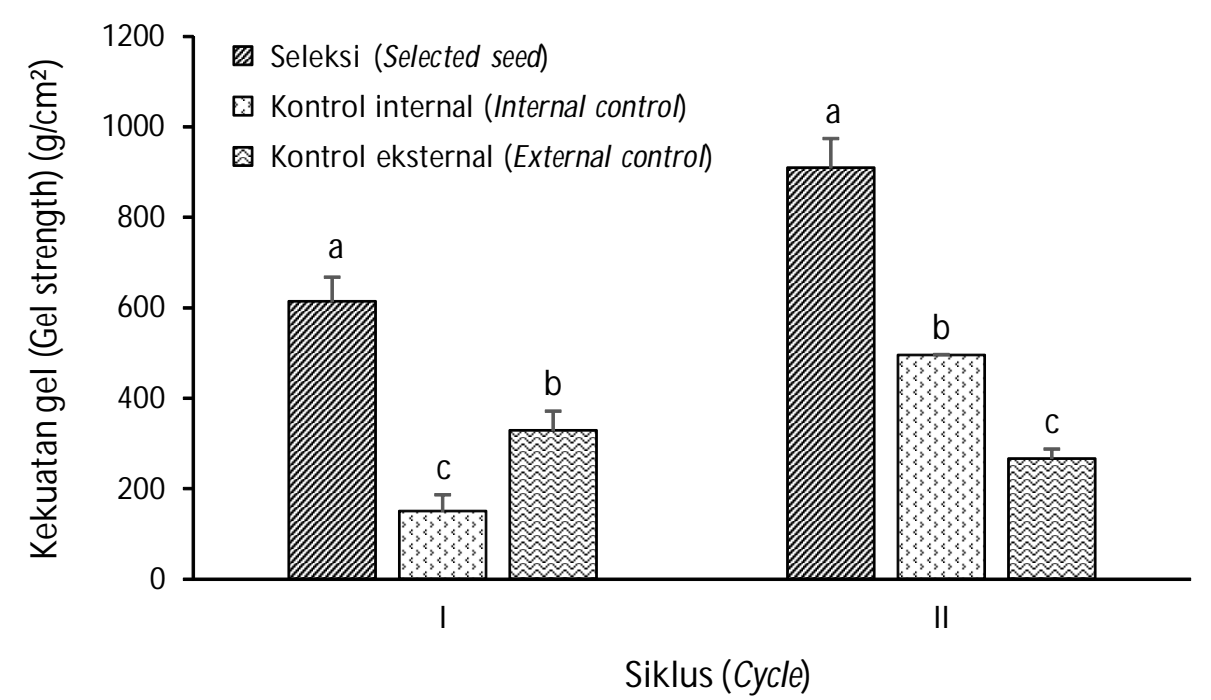

Keterangan: Nilai yang diikuti oleh huruf yang sama setelah nilai rata-rata menunjukkan tidak berbeda nyata $(P>0,05)$ pada uji Duncan

Note: $\quad$ Values with the same superscripts after means value are not significantly different $(P>0.05)$ in Duncan test

Gambar 4. Kekuatan gel rumput laut pada umur 30 hari pada siklus-I dan siklus-II.

Figure 4. Gel strength of seaweed seed after 30 days cultivation in cycle-l and cycle-Il.

laut hasil seleksi memiliki kekuatan gel yang berbeda nyata dengan kontrol internal maupun kontrol eksternal $(P<0,05)$ baik pada siklus-I maupun siklusII. Faktor umur jaringan talus diduga menjadi penyebab adanya perbedaan kualitas agar pada rumput laut hasil seleksi, kontrol internal, dan kontrol eksternal. Menurut Mendoza et al. (2006), umur jaringan talus sangat memengaruhi kuantitas dan kualitas pikokoloid yang dihasilkan.

Kekuatan gel rumput laut hasil peremajaan pada penelitian ini lebih tinggi dari hasil yang diperoleh oleh Rahim et al. (2018) yang melaporkan kekuatan gel rumput laut $\mathrm{G}$. verrucosa hasil kultur jaringan yang dibudidayakan di tambak dengan aplikasi pupuk vermikompos berada pada kisaran $65,5-77,2 \mathrm{~g} / \mathrm{cm}^{2}$. Sedangkan Rejeki et al. (2018) memperoleh kekuatan gel rumput laut $\mathrm{G}$. verrucosa hasil kultur jaringan yang dibudidayakan dengan sistem tebar dasar sebesar 478 $\pm 126 \mathrm{~g} / \mathrm{cm}^{2}$, dengan konsentrasi sampel uji sebesar $1,5 \%(\mathrm{~b} / \mathrm{v})$. Faktor-faktor yang memengaruhi kualitas agar di antaranya spesies rumput laut, lokasi budidaya, dan musim (Romero et al., 2007; Marinho-Soriano, 2001). Menurut Lee et al. (2016), kondisi lingkungan di mana rumput laut Gracilaria sp. tumbuh sangat memengaruhi kualitas agar yang dihasilkan. Perbedaan metode ekstraksi dan analisis kualitas agar yang digunakan juga dapat memengaruhi perbedaan kandungan agar dan kekuatan gel yang dihasilkan (Vuai \& M patani, 2019; Jayasinghe et al., 2016).

\section{Kualitas Air}

Dari hasil monitoring kualitas air tambak selama penelitian berlangsung diperoleh data seperti disajikan pada Tabel 4. Salinitas selama penelitian berada pada kisaran 21-30 ppt. Rumput laut Gracilaria/ Gracilariopsis merupakan spesies yang memiliki toleransi yang tinggi terhadap kisaran salinitas yakni 10-40 ppt dan tumbuh optimum pada kisaran 25-33 ppt (Kim et al., 2017).

Suhu perairan selama penelitian berada pada kisaran $28^{\circ} \mathrm{C}-30^{\circ} \mathrm{C}$. Suhu memiliki korelasi yang signifikan dengan pertumbuhan rumput laut Gracilaria, suhu terbaik untuk pertumbuhan Gracilaria pada kisaran $20^{\circ} \mathrm{C}-28^{\circ} \mathrm{C}$ (Orduña-Rojas \& Robledo, 2002; Raikar et al., 2001). Menurut Choi et al. (2006), suhu optimum untuk pertumbuhan rumput laut $\mathrm{G}$. verrucosa pada kisaran $17^{\circ} \mathrm{C}-30^{\circ} \mathrm{C}$.

Kandungan nitrat yang diperoleh selama penelitian berada pada kisaran 0,0015-0,8355 g/L. Nitrat dalam perairan diperlukan oleh rumput laut untuk metabolisme, kandungan nitrat di perairan yang optimum untuk pertumbuhan Gracilaria adalah 0,6-0,8 mg/L (Ganesan et al., 2011).

Unsur fosfat pada perairan berada pada kisaran 0,0021-0,2108 mg/L. Menurut Effendi (2003), kandungan fosfat dalam perairan digolongkan dalam tiga kategori, yakni perairan dengan tingkat kesuburan rendah memiliki kandungan fosfat pada kisaran 0-0,02 
Peremajaan bibit rumput laut Gracilaria verrucosa hasil kultur ..... (Sri Redjeki Hesti Mulyaningrum)

Tabel 4. Data kualitas air selama pemeliharaan rumput laut G. verrucosa

Table 4. Water quality during seaweed $\mathbf{G}$. verrucosa cultivation

\begin{tabular}{lcccc}
\hline $\begin{array}{c}\text { Variabel } \\
\text { Variabels }\end{array}$ & $\begin{array}{c}\text { Minimum } \\
\text { Minimum }\end{array}$ & $\begin{array}{c}\text { Maksimum } \\
\text { Maximum }\end{array}$ & $\begin{array}{c}\text { Nilai rujukan } \\
\text { Standard }\end{array}$ & $\begin{array}{c}\text { Referensi } \\
\text { Reference }\end{array}$ \\
\hline Salinitas (Salinity) $(\mathrm{ppt})$ & 21 & 30 & $25-33$ & Kim et al . (2017) \\
Suhu (Temperature) $\left({ }^{\circ} \mathrm{C}\right)$ & 28 & 30 & $17-30$ & Choi et al . (2006) \\
Nitrat (Nitrate) $(\mathrm{mg} / \mathrm{L})$ & 0.0015 & 0.8355 & $0.6-0.8$ & Lee et al . (2016) \\
Fosfat (Phosphate) $(\mathrm{mg} / \mathrm{L})$ & 0.0021 & 0.2108 & $0.1-0.2$ & Effendi (2003) \\
\hline
\end{tabular}

$\mathrm{mg} / \mathrm{L}$; tingkat kesuburan sedang pada kisaran 0,021$0,05 \mathrm{mg} / \mathrm{L}$; dan kesuburan tinggi pada kisaran 0,051$0,2 \mathrm{mg} / \mathrm{L}$. Secara umum kondisi perairan selama penelitian masih pada kondisi yang layak untuk pertumbuhan rumput laut $\mathrm{G}$. verrucosa.

Kultur jaringan merupakan salah satu metode alternatif perbanyakan klon sebagai bahan baku bibit rumput laut. Pemantauan bibit hasil kultur jaringan secara terus-menerus dan isolasi klon dengan kualitas unggul untuk sifat tertentu, serta pemeliharaan strain yang terseleksi untuk menjaga kualitas bibit hasil kultur jaringan menjadi hal yang perlu diperhatikan (Yong et al., 2014; Reddy et al., 2008; Saminathan et al., 2015). Peremajaan bibit rumput laut hasil kultur jaringan dengan metode seleksi massa merupakan salah satu upaya untuk memperbaharui bibit hasil kultur jaringan yang telah dibudidayakan secara berulang-ulang. Seleksi tidak dapat menghasilkan gen baru namun dapat merubah frekuensi gen sehingga dapat meningkatkan mutu gen secara kualitatif maupun kuantitatif. Menurut Fadilah et al. (2016), rumput laut hasil seleksi memiliki konsentrasi hormon pertumbuhan kinetin yang lebih besar dibandingkan dengan kontrol. Dengan metode seleksi diharapkan dapat memperbaiki kualitas bibit rumput laut hasil kultur jaringan sesuai dengan pendapat (Baweja et al., 2009) yang menyatakan bahwa kombinasi metode mikropropagasi dengan metode penyediaan bibit yang lain dapat meningkatkan kualitas bibit rumput laut. Untuk menjaga stabilitas mutu bibit, peremajaan sebaiknya dilakukan pada beberapa siklus hingga diperoleh bibit dengan performa yang stabil.

\section{KESIMPULAN}

Peremajaan bibit rumput laut hasil kultur jaringan dengan metode seleksi massa selama dua siklus mampu meningkatkan performa bibit rumput laut $\mathrm{G}$. verrucosa. Pertumbuhan dan kekuatan gel rumput laut hasil seleksi lebih tinggi dari kontrol internal dan kontrol eksternal, namun kandungan agar belum memperlihatkan peningkatan yang signifikan.

\section{UCAPAN TERIMA KASIH}

Penelitian ini merupakan bagian dari kegiatan diseminasi rumput laut yang dibiayai oleh APBN Tahun Anggaran 2018 Balai Riset Perikanan Budidaya Air Payau dan Penyuluhan Perikanan. Ucapan terima kasih disampaikan kepada segenap teknisi litkayasa BRPBAPPP: Bpk. Baso Muin, Bpk. Saparuddin, Ibu Haryani, dan Ibu Mujayana yang banyak membantu dalam kegiatan penelitian ini.

\section{DAFTAR ACUAN}

Ahmad, R., Surif, M., Ramli, N., Yahya, N., Nor, A.R.M., \& Bekbayeva, L. (2011). A preliminary study on the agar content and agar gel strength of Gracilaria manilaensis using different agar extraction processes. World Applied Sciences Journal, 15(2), 184-188.

Ariyanto, D. (2015). Seleksi yang tepat memberikan hasil yang hebat. Media Akuakultur, 10(2), 65-70.

Ask, E.I. \& Azanza, R.V. (2002). Advances in cultivation technology of commercial eucheumatoid species: A review with suggestions for future research. Aquaculture, 206(3-4), 257-277.

Baweja, P., Sahoo, D., García-jiménez, P., \& Robaina, R.R. (2009). Review: Seaweed tissue culture as applied to biotechnology: Problems, achievements and prospects. Phycological Research, 57(1), 45-58.

Bixler, H.J. \& Porse, H. (2011). A decade of change in the seaweed hydrocolloids industry. Journal of Applied Phycology, 23(3), 321-335.

Choi, H.G., Kim, Y.S., Kim, J.H., Lee, S.J., Park, E.J., Ryu, J., \& Nam, K.W. (2006). Effects of temperature and salinity on the growth of Gracilaria verrucosa and $G$. chorda, with the potential for mariculture in Korea. Journal of Applied Phycology, 18, 269-277.

Daud, R., Mulyaningrum, S.R.H., \& Sahrijanna, A. (2013). Pemanfaatan kebun bibit rumput laut Gracillaria sp. di tambak melalui penggunaan bibit cepat tumbuh. Prosiding Seminar Nasional Perikanan 
Indonesia Hasil Penelitian Perikanan dan Kelautan, STP, Jilid 2, 269-273.

Daud, R., Rosmiati, \& Mulyaningrum, S.R.H. (2014). Budidaya rumput laut Gracilaria sp. hasil kultur jaringan di tambak Desa Ampekale Kecamatan Bontoa Kabupaten Maros. Prosiding Seminar Nasional Tahunan Ke-IV Hasil-hasil Penelitian Perikanan dan Kelautan, Undip, Jilid 2, 399-404.

Daud, R. (2014). Perbanyakan bibit unggul rumput laut Gracilaria sp. menggunakan metode hapa di tambak Kabupaten Sinjai. Makalah disampaikan pada Seminar Nasional Tahunan XI Hasil Penelitian Perikanan dan Kelautan. Jogjakarta, 30 Agustus 2014. $5 \mathrm{hlm}$.

Daud, R., Mulyaningrum, S.R.H., \& Suryati, E. (2015). Perbanyakan rumput laut Gracilaria sp. hasil kultur jaringan di tambak. Prosiding Forum Inovasi Teknologi Akuakultur, hlm. 765-768.

Effendi, H. (2003). Telaah kualitas air bagi pengelolaan sumber daya dan lingkungan perairan. Yogyakarta: Kanisius, $257 \mathrm{hlm}$.

Fadilah, S., Alimuddin, Pong-Masak, P.R., Santoso, J., \& Parenrengi, A. (2016). Growth, morphology and growth-related hormone level in Kappaphycus alvarezii produced by mass selection in Gorontalo Waters, Indonesia. Hayati Journal of Bioscience, 23, 29-34.

FAO. (2016). The State of World Fisheries and Aquaculture 2016. Contributing to food security and nutrition for all. Rome, $200 \mathrm{pp}$.

Ganesan, M., Sahu, N., \& Eswaran, K. (2011). Raft culture of Gracilaria edulis in open sea along the south-eastern coast of India. Aquaculture, 321, 145-151.

Graham, M.H., Vásquez, J.A., \& Buschmann, A.H. (2007). Global ecology of the giant kelp Macrocystis: from ecotypes to ecosystems. Oceanography and Marine Biology Annual Review, 45, 39-88.

Hurtado, A.Q. \& Cheney, D.P. (2003). Propagule production of Eucheuma denticulatum (Burman) Collins et Harvey by tissue culture. Botanica M arina, 46(4), 338-341.

Hurtado, A.Q., Critchley, A.T., Trespoey, A., \& Lhonneur, G.B. (2006). Occurrence of Polysiphonia epiphytes in Kappaphycus farms at Calaguas Is., Camarines Norte, Phillippines. Journal of Applied Phycology, 18, 301-306.

Hurtado, A.Q., Neish, I.C., \& Critchley, A.T. (2015). Developments in production technology of Kappaphycus in the Philippines: more than four decades of farming. Journal of Applied Phycology, 27, 1945-1961.
Indriawati, K. (2007). Analisis kekuatan gel (gel strength) agar-agar komersial berdasarkan konsentrasi sulfat dan konsentrasi 3,6-anhidro-L-Galaktosa. Skripsi. Program studi biokimia MIPA. Institut Pertanian Bogor.

Jayasinghe, P.S., Pahalawattaarachchi, V., \& Ranaweera, K.K.D.S. (2016). Effect of extraction methods on the yield and physiochemical properties of polysaccharides extracted from seaweed available in Sri Lanka. Poultry, Fisheries \& Wildlife Sciences, 4(1), 1-6.

Kim, J.K., Yarish, C., Hwang, E.K., Park, M., \& Kim, Y. (2017). Seaweed aquaculture/: Cultivation technologies, challenges and its ecosystem services. Algae, 32(1), 1-13.

Lee, W.K., Lim, P.E., Phang, S.M., Namasivayam, P., \& Ho, C.L. (2016). Agar properties of Gracilaria species (Gracilariaceae, Rhodophyta) collected from different natural habitats in Malaysia. Regional Studies in Marine Science, 7, 123-128.

Luckett, D. \& Halloran, G. (2013). Plant breeding. In Pratley, J. E. (Ed.). Principles of field crop production ( $4^{\text {th }}$ ed.). South Melbourne, Victoria, Australia; New York: Oxford University Press, 73 pp.

Makmur \& Mulyaningrum, S.R.H. (2018). Evaluasi performa bibit rumput laut Gracilaria verrucosa hasil kultur jaringan di Kabupaten Luwu, Sulawesi Selatan. Media Akuakultur, 13(1), 1-9.

Marinho-Soriano, E. (2001). Agar polysaccharides from Gracilaria species (Rhodophyta, Gracilariaceae). Journal of Biotechnology, 89, 81-84.

Mendoza, W.G., Ganzon-Fortes, E.T., Villanueva, R.D., Romero, J.B., \& Montaño, M.N.E. (2006). Tissue age as a factor affecting carrageenan quantity and quality in farmed Kappaphycus striatum (Schmitz) Doty ex Silva. Botanica Marina, 49, 57-64.

Mulyaningrum, S.R.H., Daud, R., \& Badraeni. (2014). Propagasi vegetatif rumput laut Gracilaria sp. melalui kultur jaringan. Jurnal Riset Akuakultur, 9(2), 203-214.

Mulyaningrum, S.R.H. \& Suwoyo, H.S. (2018). Growth, agar yield and water quality variables affecting mass propagation of tissue cultured seaweed Gracilaria verrucosa in pond. IImu Kelautan, 23(1), 55-62.

Orduña-Rojas, J. \& Robledo, D. (2002). Studieson the tropical agarophyte Gracilaria cornea J. Agardh (Rhodophyta, Gracilariales) from Yucatán, México II. Biomass Assessment and Reproductive Phenology. Botanic Marina, 45, 459-464.

Parenrengi, A., Fahrur, M., Makmur, \& Mulyaningrum, S.R.H. (2016). Seleksi rumput laut Kappaphycus striatum dalam upaya peningkatan laju pertumbuhan 
bibit untuk budidaya. Jurnal Riset Akuakultur, 11(3), 235-248.

Pong-Masak, P.R., Priono, B., \& Insan, I. (2011). Seleksi klon bibit rumput laut, Gracilaria verrucosa. Media Akuakultur, 6(1), 1-12.

Pong-Masak, P.R. \& Sarira, N.H. (2018). Seleksi rumput laut Kappaphycus alvarezii (Rhodophyceae) dalam upaya penyediaan bibit unggul untuk budidaya. Jurnal Perikanan Universitas Gadjah Mada, 20(2), 79-85.

Rahim, A.R. (2018). Application of seaweed Gracilaria verrucosa tissue culture using different doses of vermicompost fertilizer. Nature Environment and Pollution Technology, 17(2), 661-665.

Raikar, S.V., lima, M., \& Fujita, Y. (2001). Effect of temperature, salinity and light intensity on the growth of Gracilaria spp. (Gracilariales, Rhodophyta) from Japan, Malaysia and India. Indian Journal of Marine Sciences, 30, 98-104.

Rebours, C. \& Karlsen, A. (2007). Seaweeds in the North: New scopes for coastal farming. Bioforsk Fokus, 2(13), 73-76.

Reddy, C.R.K., Jha, B., Fujita, Y., \& Ohno, M. (2008). Seaweed micropropagation techniques and their potentials: An overview. Journal of Applied Phycology, 20(5), 609-617.

Rejeki, S., Ariyati, R.W., Widowati, L.L., \& Bosma, R.H. (2018). The effect of three cultivation methods and two seedling types on growth, agar content and gel strength of Gracilaria verrucosa. Egyptian Journal of Aquatic Research, 44, 65-70. ess - uncorrected proof007/52.
Romero, J.B., Montanõ, M.N.E., Merca, F.E., Villanueva, R.D., Liao, M.L., \& Bacic, A. (2007). Seasonal variations in the composition and gel quality of agar from Gracilaria edulis in the Philippines. Botanica Marina, 50, 191-194.

Saminathan, K.R., Ashok, K.S., Veeragurunathan, V., $\&$ Mantri, V.A. (2015). Seedling production in the industrially important agarophyte Gracilaria dura (Gracilariales, Rhodophyta). Journal of Applied Phycology, 27, 1541-1548.

Titlyanov, E.A. \& Titlyanova, T.V. (2010). Seaweed cultivation: Methods and problems. Russian Journal of Marine Biology, 36(4), 227-242.

Vairappan, C.S., Chung, C.S., Hurtado, A.Q., Soya, F.E., Lhonneur, G.B., \& Critchley, A. (2008). Distribution and symptoms of epiphyte infection in major carrageenophyte-producing farms. Journal of Applied Phycology, 20(5), 477-483.

Vuai, S.A.H. \& Mpatani, F. (2019). Optimization of agar extraction from local seaweed species Gracilaria salicornia in Tanzania. Phycological Research, 67(3), 1-6.

Wikfors, G.H. \& Ohno, M. (2001). Impact of algal research in aquaculture. Journal of Phycology, 37(6), 968-974.

Yong, W.T.L., Ting, S.H., Yong, Y.S., Thien, V.Y., Wong, S.H., Chin, W.L., Rodrigues, A.F., \& Anton, A. (2014). Optimization of culture conditions for the direct regeneration of Kappaphycus alvarezii (Rhodophyta, Solieriaceae). Journal of Applied Phycology, 26(3), 1597-1606. 